\title{
Effects of Dimepiperate and Daimuron on Inhibition of Seminal Root Elongation by Chloroacetanilide Herbicides*
}

\author{
Masaru Ogasawara**, Shin-ichiro Ogawa**, Yasutomo Takeuchi** \\ and Makoto Konnai**
}

Key words : safening effect, chloroacetanilide herbicides, daimuron, dimepiperate

キーワード : 軽減効果, クロロアセトアニリド系除 草剂, ダイムロン, ジメピペレート

\section{Introduction}

Chloroacetanilide herbicides represented by pretilachlor, 2-chloro-2', 6'-diethyl- $N$-(2-propoxyethyl) acetanilide, have been widely used for control of annual grasses and some broadleaf weeds in transplanted rice in Japan. Usually, these herbicides show good selectivity between rice plant and weeds, however, they may cause rice injury when the transplanting depth and/or flooding water depth is shallow ${ }^{6,9)}$.

Ikeda and Sugaya ${ }^{5)}$ and Yuyama et al. ${ }^{11)}$ have shown that dimepiperate, $S-(\alpha, \alpha$-dimethylbenzyl) piperidine-1-carbothioate, reduced rice injury caused by the other rice herbicides such as butachlor, 2-chloro- $2^{\prime}, 6^{\prime}-$ diethyl- $N$ - (butoxymethyl) acetanilide, and bensulfuron-methyl, methyl $\alpha$-[[[( 4,6 -dimethoxypirimidin-2-yl)amino] carbonyl] sulfonyl]-otoluate.

小笠原勝・尾川新一郎・竹内安智・近内誠登 : クロロア七 トアニリド采除草剤の種子根伸長阻害に対するジメピペレ ートとダイムロンの影響

* A part of the work was presented at the 25 th Annual Meeting of the Society for the Chemical Regulation of Plants, 1990.

** Weed Science Center, Utsunomiya University, 350 Mine-machi, Utsunomiya 321, Japan.

(Received January 26, 1991)
The objective of this study was to examine the safening effects of dimepiperate and daimuron, 1-( $\alpha, \alpha$-dimethylbenzyl $)-3-p$-tolylurea, for pretilachlor and NSK-850, 2-chloro- $N$ (3-methoxy-2-thienyl)methyl-2', 6'-dimethylacetanilide, a new rice herbicide which has been developed by Tokuyama Soda Inc. ${ }^{7,8)}$, by means of the seminal root elongation test $^{10)}$.

\section{Materials and Methods}

Effects on seminal root elongation of rice (Oryza sativa L., cv. Akinishiki) and barnyardgrass (Echinochloa oryzicola Vasing.) were examined as reported earlier ${ }^{10)}$. Four herbicides used in this study were formulated as $10 \%(\mathrm{w} / \mathrm{w})$ wettable powders.

\section{Simultaneous treatment}

Rice and barnyardgrass seeds sterilized in $2 \%$ sodium hypochlorite solution for $30 \mathrm{~min}$. and rinsed in tap water were germinated at $30^{\circ} \mathrm{C}$ in the dark for 2 days. Nine germinated seeds were settled in the slits of each polyethylene disc $(5 \mathrm{~cm}$ i.d., $0.3 \mathrm{~cm}$ thick), and the discs were transferred to deep petri dishes ( $5.5 \mathrm{~cm}$ i.d., $8 \mathrm{~cm}$ tall) containing $150 \mathrm{ml}$ of test solutions. Herbicide levels were $0,0.1$, $0.3,1,3,10,30 \mathrm{ppm}$ for dimepiperate and daimuron, respectively. Combinations with pretilachlor $\left(10^{-3} \mathrm{ppm}\right)$ or with $\mathrm{NSK}-850\left(10^{-3}\right.$ $\mathrm{ppm}$ ) were also prepared for dimepiperate and daimuron at the concentrations stated above. The petri dishes were kept at $30^{\circ} \mathrm{C}$ in the dark for 3 days and then seminal root length of the plants was measured. 


\section{Separate treatment}

Nine sterilized rice seeds were soaked in $20 \mathrm{ml}$ of pretilachlor (1 ppm) or NSK-850 $(0.3 \mathrm{ppm})$ solution for 2 days, and then rinsed in tap water for $3 \mathrm{hr}$. The seeds were then placed polyethylene discs ( 9 seeds/disc) which were subsequently transferred to deep petri dishes containing $150 \mathrm{ml}$ of dimepiperate $(0,0.1,0.3,1,3,10,30 \mathrm{ppm})$ or daimuron $(0$, $0.1,0.3,1,3,10,30 \mathrm{ppm}$ ) solutions for 3 days. Alternatively, the sterilized rice seeds were treated with dimepiperate $\left(10^{-1}, 1,10,10^{2}, 10^{3}\right.$ $\mathrm{ppm})$ or daimuron $\left(10^{-1}, 1,10,10^{2}, 10^{3} \mathrm{ppm}\right)$ for 2 days, and then the polyethylene discs with 9 seeds were transferred to the deep petri dishes containing $150 \mathrm{ml}$ of pretilachlor $\left(10^{-3} \mathrm{ppm}\right)$ or NSK-850 $\left(10^{-3} \mathrm{ppm}\right)$ solution. All treatments were conducted at $30^{\circ} \mathrm{C}$ in the dark, and seminal root length of rice plants was measured 5 days after the beginning of the first treatment. All experiments were replicated three times and mean values of seminal root length of the plants were obtained.

\section{Results and Discussion}

\section{Simultaneous treatment}

In rice plants, dimepiperate and daimuron

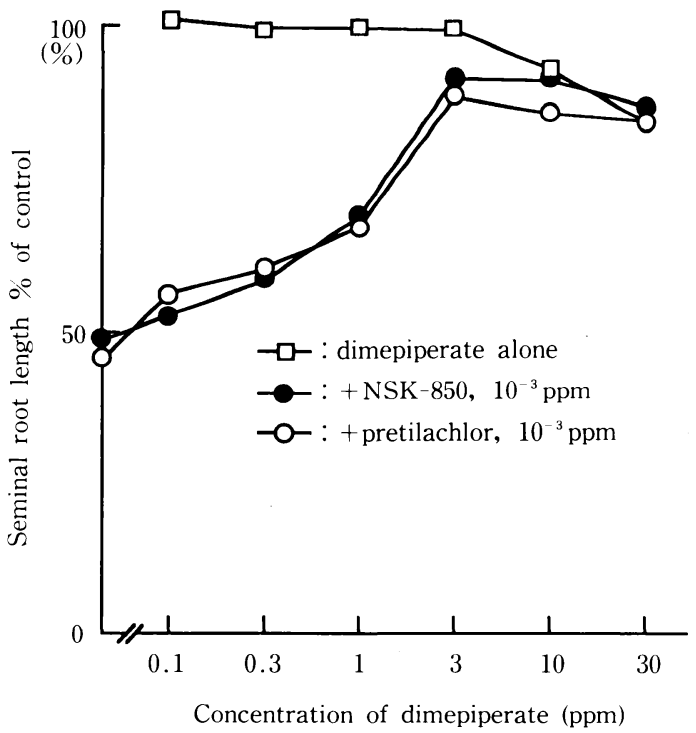

inhibited the seminal root elongation by about $20 \%$ at the highest concentration ( $30 \mathrm{ppm}$ ), while pretilachlor and NSK-850 caused $51 \%$ and $54 \%$ inhibition at $10^{-3} \mathrm{ppm}$, respectively. When $10^{-3} \mathrm{ppm}$ pretilachlor or $10^{-3} \mathrm{ppm}$ NSK850 was applied together with dimepiperate, the inhibition decreased linearly with increasing dimepiperate concentration from $0.1 \mathrm{ppm}$ to $3 \mathrm{ppm}$. Daimuron also reduced the inhibition and the safening effect was significant even at $0.1 \mathrm{ppm}$ (Fig. 1).

In barnyardgrass, the inhibition of seminal root elongation by pretilachlor and NSK-850 was diminished in the presence of dimepiperate, whereas daimuron did not reduce the inhibition (Fig. 2). These results demonstrated that dimepiperate reduced the inhibition of seminal root elongation by pretilachlor and NSK-850 in both the rice plants and the weed, but daimuron was effective as a safener only in the rice plants.

\section{Separate treatment}

Effects of dimepiperate and daimuron on the inhibition of rice seminal root elongation by the chloroacetanilides were examined by changing the sequence of treatments. When the rice plants were treated with $1 \mathrm{ppm}$ pre-

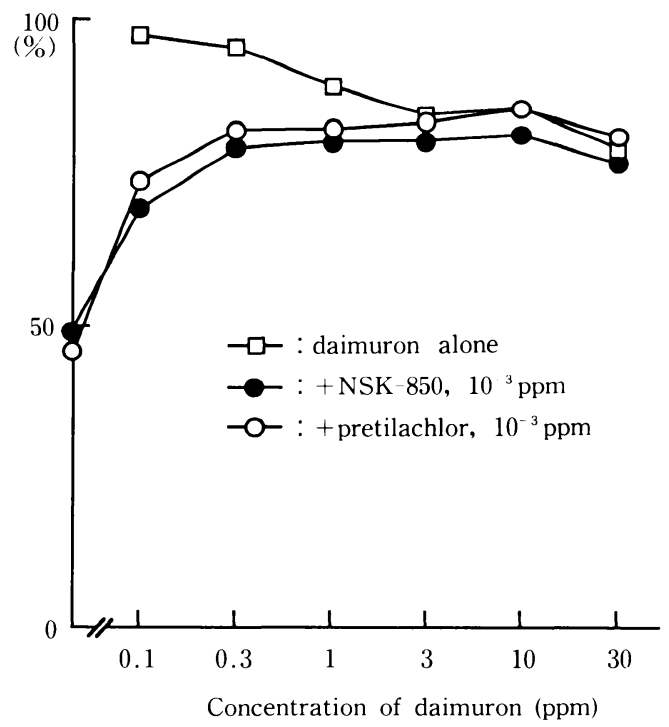

Fig. 1. Safening effects of dimepiperate and daimuron on pretilachlor and NSK-850 inhibition by simultaneous treatment. Seminal root length of rice plants was measured 3 days after treatment. 

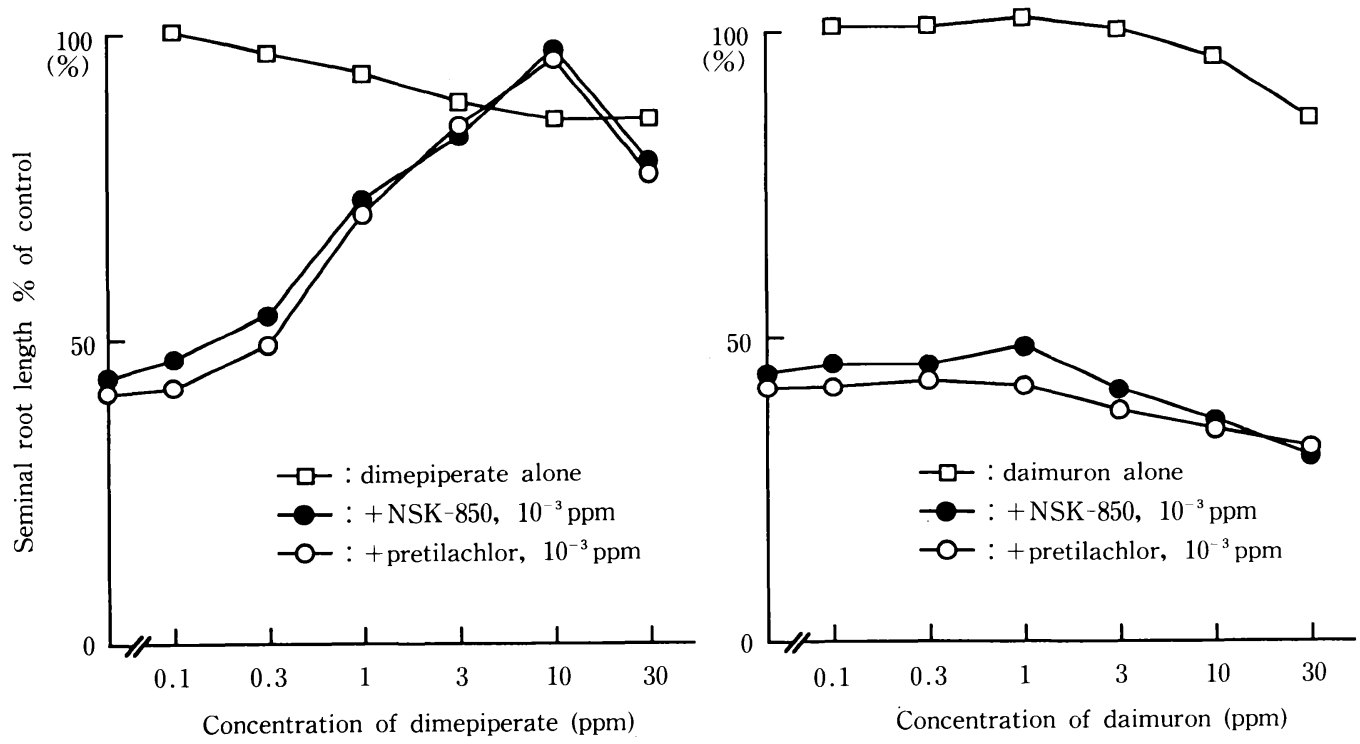

Fig. 2. Safening effects of dimepiperate and daimuron on pretilachlor and NSK - 850 inhibition by simultaneous treatment. Seminal root length of barnyardgrass was measured 3 days after treatment.
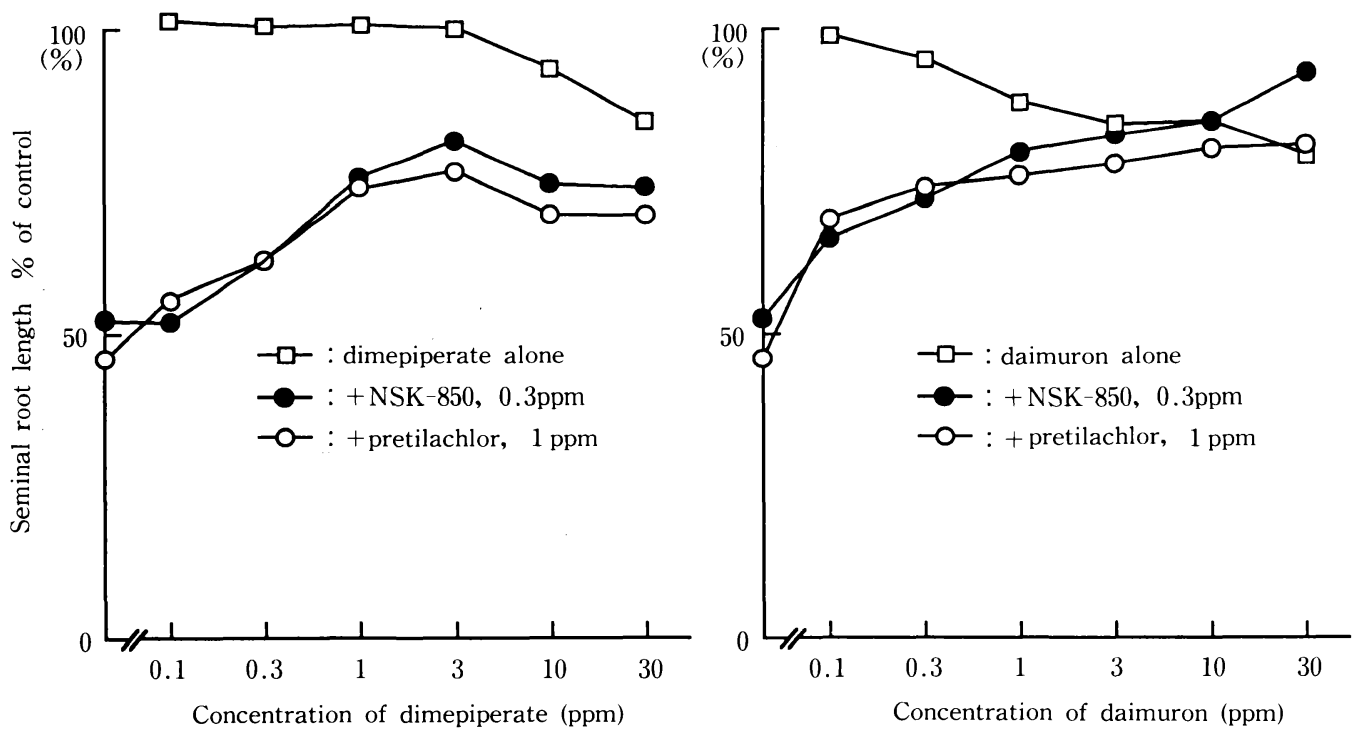

Fig. 3. Safening effects of dimepiperate and daimuron on pretilachlor and NSK-850 inhibition by separate treatment. Pretilachlor and NSK - 850 treatments were followed by dimepiperate and daimuron treatments. Seminal root length of rice plants was measured 5 days after treatment.

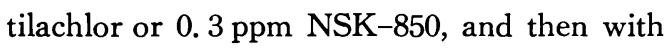
$3 \mathrm{ppm}$ dimepiperate, $54.0 \%$ and $47.0 \%$ inhibition by pretilachlor and NSK-850 fell to $23.5 \%$ and $18.0 \%$, respectively. Similar effects were also observed with daimuron (Fig.
3). These results suggest possibilities that dimepiperate and daimuron act as safeners in rice plants by promoting degradation and/ or metabolism of the chloroacetanilides. In fact, Yuyama et al. reported that the safen- 

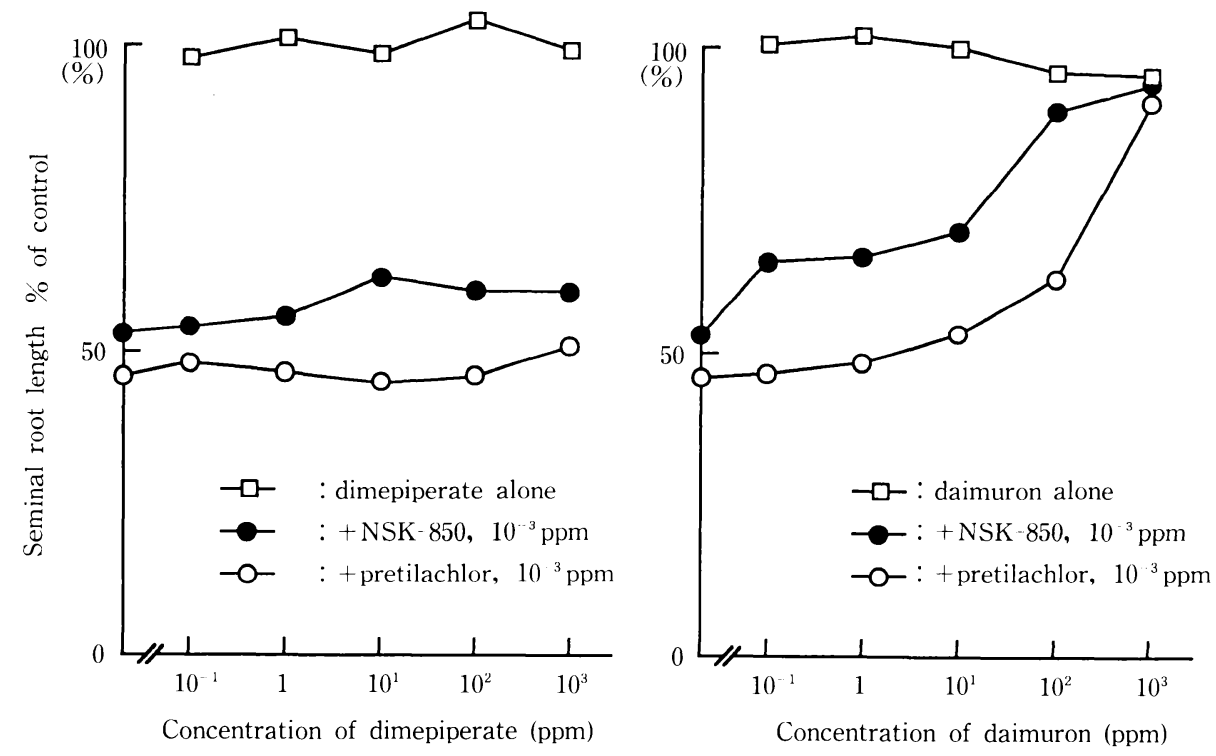

Fig. 4. Safening effects of dimepiperate and daimuron on pretilachlor and NSK-850 inhibition by separate treatment. Dimepiperate and daimuron treatments were followed by pretilachlor and NSK850. Seminal root length of rice plants was measured 5 days after treatment.

ing effect of dimepiperate on bensulfuronmethyl injury to rice plants could be attributed to the increased herbicide metabolism in the plants ${ }^{11}$.

When altering the sequence of treatments so that the plants were exposed to dimepiperate or daimuron before their contact with pretilachlor or NSK-850, the inhibition by the chloroacetanilides was decreased by daimuron, but not by dimepiperate (Fig. 4), indicating that daimuron may not only enhance the detoxification activity, but may reduce the absorption and translocation of the chloroacetanilides in rice plants.

Extensive studies on herbicide safeners have been reported ${ }^{1,2)}$. Fuerst and Grownwald found that flurazole, benzyl 2-chloro-4-(trifluoromethyl)-5-thiazolecarboxylate, and CGA92194, $\alpha$-[(1, 3-dioxolan-2-yl-methoxy)imino] benzeneacetonitrile, protected sorghum from metolachlor, 2-chloro-2', 6'-diethyl- $\mathrm{N}$-(methoxymethyl)acetanilide, injury by enhancing metabolism through conjugation with glutathione ${ }^{3)}$. Hatzios and Hoagland classified the safening mechanisms of herbicide into three categories : a) promotion of degradation or metabolism of herbicides in plants, b) inhibition of absorption or translocation of herbicides in plants, and c) a process involving all of the aboves). Although in the seminal root elongation test dimepiperate and daimuron were found to act as safeners for pretilachlor and NSK-850, further study is needed to clarify the safening mechanisms.

\section{References}

1) Christ, R. A. 1984. Effect of CGA-123407 as a safener for pretilachlor in rice (Oryza sativa L.). Recordings of Elongation Rates of Single rice leaves. Weed Res., 25, 193-200.

2) Ekler, Z. and G.R. Stephenson 1989. Physiological responses of maize and sorghum to four different safeners for metazachlor. Weed Res., 29, 181-191.

3) Fuerst, E.P. and J.W. Grownwald 1986. Induction of rapid metabolism of metolachlor in sorghum (Sorghum bicolor) shoots by CGA-92194 and other antidotes. Weed Sci., 34, 354-361.

4) Hatzios, K.K. and R.E. Hoagland 1989. Crop safener for herbicides : development, uses, and mech- 
anisms of action; Academic : San Diego.

5) Ikeda, K. and K. Sugaya 1989. Safening action of dimepiperate on herbicides inhibiting root growth of rice plant. Weed Res. Japan, 34, 37-46 (in Japanese with English summary).

6) Murakami, S. and L. Ebner 1983. Pretilachlor a new selective herbicide for transplanted rice in Japan. proceedings 9 th conference of the Asian Pacific Weed Sci. Soc., 405-412.

7) Ogasawara, M., M. Konnai, T. Takematsu, S. Katoh and M. Ishizaki 1989. Herbicidal activity of $\alpha$-chloroacetanilide derivatives. Weed Res. Japan, 34, 131-137 (in Japanese with English summary).

8) Ogasawara, M., M. Konnai, T. Takematsu, S. Katoh and M. Ishizaki 1989. Properties of a new Herbicide, NSK-850. Weed Res. Japan, 34, 138-
145 (in Japanese with English summary).

9) Ogasawara, M., K. Ishikawa and M. Konnai 1990. Effects of depth of flooding water on rice injury Caused by $\alpha$-Chloroacetanilide Herbicides. Weed Res. Japan 35, 102-108 (in Japanese with English summary).

10) Ogasawara, M., Y. Watanabe, S. Ogawa and M. Konnai 1990. Seminal root elongation test as a new bioassay method for the evaluation of herbicide action. Weed Res. Japan 35, 95-101. (in Japanese with English summary).

11) Yuyama, T., P. B. Sweetser, R. C. Ackerson and S. Takeda 1986. Safening of DPX-F 5384 on rice by combination with thiocarbamate herbicides. Weed Res. Japan 31, 164-170.

\title{
埼玉県の桑園におけるパラコート抵抗性ヒメムカショモギの 分布実態について*
}

\author{
埴岡 靖男**
}

キーワード : ヒメムカショモギ, パラコート抵抗性, 分布

Key words : Erigeron canadensis L., resistant to paraquat, distribution

パラコート抵抗性ヒメムカショモギは, 1980年に大 阪府下のブドウ園で初めて観察され ${ }^{3)}$, その後羽曳野 市, 柏原市および神戸大学構内固場等, 関西を中心に 分布が確認されている。しかし, 関東地方における分 布状況は佐藤ら 5 の報告がある程度である。

筆者は1986年に埼玉県内の桑園等においても抵抗性 ヒメムカショモギの分布を確認し，その分布実態を 1986年および1988年に調査したのでその概要を報告す る。

\footnotetext{
* 一部は日本虫系学会第57回講演会（1987年 4 月）におい て発表した。

** 埼玉県虫業試験場
}

Yasuo Hanioka: Studies on the Distribution of Erigeron canadensis L. Resistant to Paraquat in Mulberry Fields in Saitama Prefecture (1991年 3 月 4 日受理)

\section{材料および方法}

分布実態調查 : 調查は $10 \mathrm{a}$ 前後の桑園を 1 地点とし て，1986年 5 月（235 地点）および 1988年 6 月下旬〜 7 月上旬 (243 地点) の 2 回実施した。対象地域は 埼 玉県内の主な養亘地帯 5 地域, 即ち, 熊谷市近辺, 吹 上町 - 大里村河川敷, 川本町 - 江南町, 坚玉町 - 美里 町 (1986年のみ), 東松山市丘陵地 (1988年のみ), 秩 父市・皆野町山間地を選定した。

各地点では, 観察により発生が多い順に10位までの 草種を記録し，ヒメムカショモギの発生地点を調査地 点数で除して出現率を求めた。また, 平均順位は出現 した地点での発生順位の平均を示した。ヒメムカショ モギが出現した地点では，葉を採取して抵抗性の検定 を行った。

試料の採取と検定方法 : ヒメムカショモギの抵抗性 検定方法はおおむね渡辺ら ${ }^{6)}$ の方法によった。即ち， 桑園 1 地点あたり無作意に 5 ～20個体を選び, 各個体 から 1 葉ずつ採取し, 直径 $8 \mathrm{~mm}$ のリーフパンチで打 ち抜いた後, $10 \mathrm{ppm}$ のパラコート溶液 $(10 \mathrm{ml} /$ 直径 9 